\title{
Acute transformation of essential thrombocythaemia: report of two cases
}

\author{
A M O'HEA,* W ERBER,* N T J O'CONNOR, C BUNCH \\ From the Nuffield Department of Clinical Medicine and the *Department of Haematology, John Radcliffe \\ Hospital, Oxford
}

SUMMARY Two cases of leukaemic transformation are reported, one to acute lymphoblastic leukaemia associated with a $14 \mathrm{q}^{+}$marker chromosome and the other to acute monocytic leukaemia, occurring 20 and 30 years, respectively, after the original diagnosis was made.

Essential thrombocythaemia is one of the myeloproliferative disorders, a category that also includes polycythaemia rubra vera, chronic granulocytic leukaemia, and myelofibrosis. These disorders are characterised by proliferation of one or more of the erythrocytic, granulocytic, and megakaryocytic components of the marrow, and they have been shown to have a clonal origin from a single pluripotent stem cell. ${ }^{12}$ Reports of the progression of essential thrombocythaemia to acute myeloid leukaemia are rare, and those reported occurred shortly after large doses of ${ }^{32} \mathrm{P}$ or other chemotherapy. ${ }^{3-10}$

\section{Case reports}

\section{CASE 1}

In 1968 a 55 year old woman presented with a one week history of rapid deterioration of vision in her right eye: retinal vein thrombosis was diagnosed. Her spleen was not palpable but was noted to be enlarged on a barium meal study. At presentation the haemoglobin was $13.7 \mathrm{~g} / \mathrm{dl}$, reticulocytes $1 \%$, white cell count $7.6 \times 10^{9} / 1$ with a normal differential and platelets at $1378 \times 10^{9} / 1$. A bone marrow aspirate showed increased numbers of megakaryocytes, normal erythropoiesis, and adequate iron stores. The platelets rapidly returned to normal after treatment with $5 \mathrm{mCi}^{32} \mathrm{P}$. Over the next 11 years she remained well apart from an acute attack of gout, but she required three further injections of ${ }^{32} \mathrm{P}$ to control her platelet count. A total dose of $15 \mathrm{mCi}$ was given.

In 1979 at routine follow up she was found to have a normochromic normocytic anaemia of $9.5 \mathrm{~g} / \mathrm{dl}$, a bone marrow showing severe dyserythropoiesis, and a hypercellular trephine biopsy specimen showing large numbers of abnormal megakaryocytes and increased reticulin. She subsequently became transfusion dependent, but in 1982 her anaemia spontaneously improved and further transfusion was unnecessary. Her peripheral blood film at that time showed occasional myelocytes, normoblasts, and tear drop cells, and the platelet count varied between 40 and $120 \times$ $10^{9} / 1$.

In February 1984 she was admitted with a left lower lobe pneumonia, hepatomegaly of $6 \mathrm{~cm}$, and splenomegaly of $12 \mathrm{~cm}$. Her haemoglobin was $7 \cdot 6$ $\mathrm{g} / \mathrm{dl}$, white cell count $22.6 \times 10^{9} / 1$ with $60 \%$ blasts, and platelets $82 \times 10^{9} / 1$. Cytogenetic analysis showed all cells examined to be $44 \mathrm{XX}$ with absent chromosomes 7,21 , and $14 \mathrm{q}^{+}, 6 \mathrm{p}^{-}$. The blasts were myeloperoxidase and periodic acid Schiff negative, but immunophenotyping using the APAAP immunoalkaline phosphatase labelling technique ${ }^{1112}$ showed that the cells were lymphoblasts with evidence of early $\mathrm{T}$ cell differentiation; and some cells showed evidence of $B$ cell differentiation (table). On the basis of the immunocytochemical results acute lymphoblastic transformation of essential thrombocythaemia was diagnosed. DNA from the peripheral blood blasts was analysed for evidence of gene rearrangement. The three probes used were an immunoglobulin heavy chain joining region $J_{H}$ probe (C76R51A); an immunoglobulin $\kappa$ chain probe $C_{k}$ (pUCR17k), and a TCR $\beta$ gene probe (Jurkat $\beta 2$ ). After digestion with BamHI and EcoRI ( $\mathrm{J}_{\mathrm{B}}$ probe), BamHI $\left(C_{k}\right.$ probe) and EcoRI, HindIII and BamHI (TCR $\beta$ chain) the blast cell DNA showed a germline configuration after hybridisation with both $\operatorname{TCR} \beta$ chain gene probe and the immunoglobulin gene probes.

She was treated with vincristine and prednisolone, but the leucocyte count and the proportion of blasts continued to rise. She required regular transfusion over the next few months and had frequent admis- 
Table Immunophenotyping of results for case 1

\begin{tabular}{lllr}
\hline Monoclonal antibody & Antibody directed against: & Source & (\%) blasts positive \\
\hline CR3/43 & HLA-DR & DY Mason & 100 \\
TdT & Terminal transferase & Supertechs & 72 \\
AN51 & Platelet glycoprotein I & A McMichael & 0 \\
C17 & P Tetteroo & 0 \\
Tu 69 & Platelet glycoprotein IIIa & A Ziegler & 90 \\
Tu 93 (CD7) & Interleukin-2 receptor & A Ziegler & 85 \\
TO 15 (CD22) & Pan T cell & DY Mason & 30 \\
UCHT1 (CD3) & Pan B cell & P Beverley & 0 \\
T, & Rieth T (T) & & 0 \\
\hline
\end{tabular}

sions with fever and chest infections. Five months after the acute transformation she again developed a left sided pneumonia, rapidly deteriorated, and died. Necropsy showed extensive leukaemic infiltration of the marrow and spleen with numerous blast cells.

\section{CASE 2}

A 45 year old man presented in 1955 with left hypochondrial pain and indigestion. A barium meal showed a paraoesophageal hernia and splenomegaly. His haemoglobin was $15.7 \mathrm{~g} / \mathrm{dl}$, reticulocytes $1 \cdot 2 \%$, white cell count $9.8 \times 10^{9} / 1$ with a normal differential, and platelets $771 \times 10^{9} / 1$. The bone marrow was cellular with increased numbers of megakaryocytes. His abdominal symptoms settled with antacid treatment. Over the next 10 years his platelet count remained raised between $650-979 \times 10^{9} / 1$, but in 1965 it rose to $1896 \times 10^{9} / 1$. At this time his spleen was just palpable. Treatment with $5 \mathrm{mCi}{ }^{32} \mathrm{P}$ was given, and a further $3 \mathrm{mCi}^{32} \mathrm{P}$ was given four months later. His platelet count remained between $500-1000$ $\times 10^{9} / 1$ until 1973 , when it spontaneously returned to normal.

He presented again in May 1985 with confusion, ascites, and hepatosplenomegaly. His haemoglobin was $11.5 \mathrm{~g} / \mathrm{dl}$, white cell count $226 \times 10^{9} / 1$ with $100 \%$ monoblasts, and platelets $71 \times 10^{9} / 1$. Immunophenotyping showed that the blasts did not show any lymphoid or megakaryoblastic differentiation but were strongly positive with EB11 (a monoclonal antibody reacting with monocytes), ${ }^{13}$ and also weakly myeloperoxidase positive. Cytogenetic analysis showed trisomy 6 and 8 in all cells examined. Management was supportive, and no specific treatment for his acute transformation was given. He became increasingly confused and drowsy and died 48 hours after his admission. Permission for necropsy was refused, but it was assumed that his rapid deterioration was due to leucostasis.

\section{Discussion}

These cases confirm that transformation to acute leukaemia may occur in essential thrombocythaemia. This may be a late event in the course of the disease, and in these two patients occurred in spite of only occasional doses of ${ }^{32} \mathrm{P}$, totalling $15 \mathrm{mCi}$ and $8 \mathrm{mCi}$, respectively. The leukaemogenic potential of ${ }^{32} \mathrm{P}$ is less clearly defined than that associated with alkylating agents, ${ }^{1415}$ and therefore it is most likely that leukaemic transformation in these two patients occurred as part of the natural history of essential thrombocythaemia.

The nature of the transformation in our first patient is also of interest. Lymphoblastic transformation occurs in about $20 \%$ of patients with chronic granulocytic leukaemia, but is less common in polycythaemia rubra vera and has not been reported previously in essential thrombocythaemia. As in chronic granulocytic leukaemia, lymphoid transformation may be taken as another indicator of the pluripotent stem cell origin of the underlying disease. Although immunophenotyping suggested transformation to an early lymphoblast with features of both $B$ and $T$ cell differentiation, we were unable to confirm rearrangement of immunoglobulin or $\mathrm{T}$ cell receptor $\beta$ (TCR $\beta$ ) genes. As Ig rearrangement is thought to be the earliest event in $B$ cell differentiation, this excludes a $\mathrm{B}$ cell genotype. ${ }^{16} \mathrm{On}$ the other hand, $\mathrm{T}$ cell differentiation cannot be excluded as $\mathrm{T}$ cell leukaemias derived from primitive $\mathrm{T}$ cells commonly fail to show TCR $\beta$ rearrangement. $^{17}$

Cytogenetic abnormalities have been described in essential thrombocythaemia, the deletion of the long arm of chromosome $21\left(21 \mathrm{q}^{-}\right)$with a translocation entailing $11 \mathrm{q}$ being a common finding. ${ }^{1819}$ Absence of chromosome 21 was noted in our first patient at the time of transformation, but it is not clear if this and the other chromosome abnormalities occurred at the time of transformation. The $14 \mathrm{q}^{+}$noted in this patient occurs commonly in lymphoid malignancies, including B cell ALL and non-Hodgkin's lymphoma of B or T cell type. ${ }^{20}$ The donor chromosome for this translocation was not identified in our case, and as cytogenetic studies were not performed before the acute transformation it is impossible to be certain that the emergence of this clone coincided with the transformation to acute lymphoblastic leukaemia. 
WNE is in receipt of a Rhodes scholarship, and NTJO'C a Medical Research Council training fellowship. We thank Dr Tak Mak for the jurkat $\beta 2$ probe and Dr T H Rabbitts for the Ig gene probes.

\section{References}

1 Fialkow PJ, Faguet GB, Jacobson RJ, et al. Evidence that essential thrombocythaemia is a clonal disorder with origin in a multipotent Stem Cell. Blood 1981;58:916-9.

2 Gaetani GF, Ferraris AM, Galiano S, et al. Primary thrombocythaemia: clonal origin of platelets, erythrocytes, and granulocytes in a $\mathrm{Gd}^{\mathrm{B}} / \mathrm{Gd}$ Mediterranean subject. Blood 1982; 59:76-9.

3 McCabe WR, Bind RM, McLaughlin RA. Is primary haemorrhagic thrombocythaemia a clinical myth? Ann Intern Med 1955; 43:182-90.

4 Ozer FL, Traux WE, Miesch DC, et al. Primary haemorrhagic thrombocythaemia. Am J Med 1960;28:807-23.

5 Fickers M, Speck B. Thrombocythaemia. Acta Haematol 1974;51:257-65.

6 Geller SA, Shapiro E. Acute leukaemia as a natural sequel to primary thrombocythaemia. Am J Clin Pathol 1982;77:353-6.

7 Ratti M, Ghio R, Casciaro S, Ratterri S, Boccaccio P. Acute promyelocytic leukaemia developing in essential thrombocythaemia: blastic crisis or secondary acute leukaemia? Haematologica 1984;69:330-5.

8 Simon M, Jouet P, Huart J, Demory JL, Banters F. La thrombocytemie essentialle. Sem Hôp Paris 1984;60::1173-9.

9 Fukushima Y, Yasunori K, Mitsuyuki F, Yamaguchi A, Miura A. A case of essential thrombocythaemia terminated in acute myeloblastic leukaemia. Rinsho Ketueki 1984;25:712-8.

10 Raman S, Mahmood A, Van Slyck EJ, Saad SM. Essential thrombocythaemia with transition into acute leukaemia. Ann NY Acad Sci 1981;370:145-53.

11 Cordell JL, Falini B, Erber WN, et al. Immunoenzymatic label- ling of monoclonal antibodies using immune complexes of alkaline phosphatase and monoclonal anti alkaline phosphatase (APAAP) complexes. J Histochem Cytochem 1984;32:219-29.

12 Erber WN, Mynheer LC, Mason DY. APAAP labelling of blood $\widehat{\sigma}$ and bone marrow samples for phenotyping leukaemia. Lancet $\tau$ 1986;i:761-5.

13 Franklin WA, Falini B, Pulford KAF, et al. Heterogeneity of the mononuclear phagocytes. In: Gregnani F, Martelli MF, Mason DY, eds. Monoclonal antibodies in haematopathology. New York: Raven Press, 1985:191-200.

14 Lawrence JH, Winchell HS, Donald WG. Leukaemia in polycythaemia vera. Ann Intern Med 1969;70(4):763-71.

15 Berk PD, Goldberg JD, Murray SN, et al. Incidence of acute leukaemia in polycythaemia vera associated with chlorambucil therapy. $N$ Engl $J$ Med 1981;304:441-7.

16 Korsmeyer SJ, Arnold A, Bakshi A, et al. Immunoglobulin gene rearrangement and cell surface antigen expression in acute lymphoblastic leukaemias of T-cell and B-cell precursor origins. J Clin Invest 1983;71:301-13.

17 Roye HD, Acuto O, Fabbi M, et al. Genes encoding the Ti $\beta$ subunit of the antigen/MHC receptor undergo rearrangement $\vec{N}$ during intrathymic ontogeny prior to surface T3-Ti expression. Cell 1984;39:261-6.

18 Zaccaria A, Tura S. A chromosomal abnormality in primary thrombocythaemia. $N$ Engl J Med 1978;298:1422-3.

19 Van den Berghe H, Petit P, Brockaert-Van Orshoven A, et al. A chromosomal abnormality $\left(21 \mathbf{q}^{-}\right)$in primary thrombocytosis. Hum Genet 1979;50:105-6.

20 Rowley JD, Fukuhara S. Chromosome studies in non-Hodgkins lymphomas. Semin Oncol 1980;7:255-66.

Requests for reprints to: Dr A M O'Hea, Department of Haematology, John Radcliffe Hospital, Headington, Oxfor OX3 9DU, England. 